Karol Martyniak

\title{
Objazd naukowy po Ukrainie
}

W dniach 3-8 listopada 2010 roku, odbył się objazd naukowy, mający na celu poznanie najdalszych, południowo-wschodnich kresów dawnej Rzeczpospolitej. Był to wyjazd specjalności Europa Wschodnia, funkcjonującej w ramach Wydziału Historii i Dziedzictwa Kulturowego UPJPII w Krakowie. Merytoryczną pomocą i opieką służyli studentom: dziekan Wydziału ks. dr hab. Józef Wołczański, prof. UPJPII, ks. dr hab. Jan Szczepaniak, prof. UPJPII, dyrektor Instytutu Historii ks. prof. dr hab. Bogdan Stanaszek, prof. dr hab. Maciej Salamon oraz prodziekan Wydziału dr Marek Hałaburda.

Plac przed Domem Turysty w Krakowie stał się punktem zbornym dla wyruszających na tę niecodzienną wyprawę. Trasą poprzez Brzesko, Tarnów, Dębicę, Ropczyce, Rzeszów, Przeworsk i Jarosław dotarliśmy do przejścia granicznego w Korczowej. Oczekiwanie na przekroczenie granicy nie okazało się zbyt długie ani uciążliwe. Szlakami Ukrainy pojechaliśmy w głąb kraju. Przez okna autokaru podziwialiśmy położony w cieniu Wysokiego Zamku gród Lwa. Kocie łby z czasów Monarchii Austro-Węgierskiej spowolniły jazdę, jednak przy okazji można było przyjrzeć się dawnym koszarom, gmachowi Opery oraz położonej na wzgórzu katedralnej cerkwi św. Jura. Dzięki zapobiegliwości organizatorów pozornie monotonne podróżowanie i siedzenie godzinami w autokarowym fotelu mijało niezwykle szybko, bowiem wyświetlano ciekawe dokumentalne filmy o przeszłości tych ziem i stosunkach polsko-ukraińskich. Studenci prezentowali także przygotowane wcześniej referaty na temat miejsc, które odwiedzaliśmy. Autorzy wykazujący się największym krasomówstwem bądź operujący w swojej pracy znakomitym aparatem naukowym byli nagradzani gromkimi brawami. Za Lwowem zatrzymaliśmy się na kilka chwil w Złoczowie. Dalsza droga wiodła przez Tarnopol i Chmielnicki aż do miejsca noclegu, podolskiego Latyczowa, znanego miejsca kultu Matki Bożej. W dawnym klasztorze dominikanów, obecnie domu pielgrzymkowym, spędziliśmy trzy noce. Było to iście warowne miejsce, otoczone z każdej strony kamiennym murem i basztami. Serdecznie przyjęci przez gospodarza, ks. Adama Przywuskiego, byliśmy pod wrażeniem okazanej nam gościnności. 
Czwartek, 4 listopada, rozpoczęliśmy od wyjazdu do pobliskiego Brahiłowa. Niestety, kościół będący miejscem kultu Cudownego Figury Pana Jezusa (figurę mieli przywieźć trynitarze aż z Madrytu) okazał się zamknięty na głucho, a próby odnalezienia w pobliżu gospodarza obiektu nie powiodły się. Zobaczyliśmy za to dwór, w którym wczasował się swego czasu sam Piotr Czajkowski. Następnym przystankiem był znany z historii i literatury Bar. Zwiedziliśmy kościół rzymskokatolicki, słuchając opowieści pracującego tam wikarego. W miasteczku przyglądaliśmy się również pozostałościom twierdzy oraz klasztorowi Karmelitów. Jadąc dalej, podziwialiśmy z daleka majestatyczną sylwetkę „białego łabędzia”, potężnej twierdzy w Międzybożu. Jej historia związana jest z rodem Sieniawskich, a kwaterował w niej m.in. Tadeusz Kościuszko. Zwiedziliśmy warownię oraz urządzoną w kilku salach ekspozycję, przybliżającą temat sztucznie wywołanego przez sowieckie władze wielkiego głodu na Ukrainie. Nieopodal była jeszcze okazja zobaczyć ruiny kościoła św. Trójcy oraz cmentarz żydowski, na którym pochowano Israela ben Eliezera, według tradycji twórcy chasydyzmu.

W piątek zwiedzanie rozpoczęliśmy od położonego dalej na wschód miasta Winnicy. Na naszym szlaku znalazły się najciekawsze zabytki ulicy Sobornej: dawny kościół Dominikanów (po powstaniu listopadowym zamieniony na cerkiew), kościół kapucynów pw. Matki Bożej Anielskiej (tutaj po kościele, klasztorze i podziemiach oprowadził nas jeden $\mathrm{z}$ braci) oraz dawny klasztor Jezuitów (obecnie archiwum). W Woronowicy podziw budził (mimo zaniedbanego stanu) pałac Grocholskich. Dziś mieści on w swoich murach muzeum lotnictwa, bowiem mieszkał tu jeden z pionierów tej dziedziny, rosyjski admirał Aleksander Możajski. Niemirów przywitał nas dosyć kontrastowym widokiem, bowiem postać Lenina na pomniku zdawała się zmierzać w stronę stojącego naprzeciw rzymskokatolickiego kościoła św. Jozefa. Widzieliśmy tam również klasycystyczny pałac Potockich z parkiem. O Bracławiu, dawnej stolicy województwa, dziś prowincjonalnej mieścinie, dowiedzieliśmy się więcej dzięki opowieściom siostry zakonnej, pełniącej służbę przy tamtejszym kościele. Kierując się na południe nie mogliśmy ominąć Tulczyna, wstępując do zamienionego na cerkiew dawnego kościoła Dominikanów z wielkim pomnikiem Suworowa przed frontem świątyni oraz do „kresowego Wersalu”, dawnej rezydencji magnackiej Potockich. Ostatnim przystankiem tego dnia, już nieopodal mołdawskiej granicy, był położony na wzgórzach Szarogród, typowe kresowe miasteczko, pełne świadectw wielokulturowości. Obejrzeliśmy barokowy kościół Bernardynów (o parafii opowiadał miejscowy franciszkanin), dawny unicki monastyr oraz renesansową synagogę. Mała awaria autobusu okazała się dobrą okazją do bliższego poznania tego miejsca. Korzystając z ostatnich promieni słońca, oświetleni blaskiem 
różowoczerwonego nieba i owiani ciepłym wiatrem z południa, spacerowaliśmy główną ulicą miasteczka. Kończył się kolejny dzień wyprawy.

W sobotni poranek pożegnaliśmy Latyczów, kierując się na północ. Pierwszy przystanek został zarządzony w Chmielniku. Wstąpiliśmy do kościoła, w którym został ochrzczony Ignacy Jan Paderewski i przeszliśmy się po terenie zespołu pałacowo-parkowego. Potem przyszedł czas na Berdyczów, dawniej największy ośrodek handlowy prawobrzeżnej (polskiej) Ukrainy oraz popularne także i dziś miejsce pielgrzymkowe. Zachwyt budził szczególnie obwarowany jak forteca barokowy kościół i klasztor Karmelitów bosych. Zwiedziliśmy górny, pięknie odnowiony kościół oraz dolny, gdzie mieści się kopia cudownego wizerunku Matki Bożej, a także ekspozycja poświęcona pochodzącemu z Berdyczowa Józefowi Korzeniowskiemu (Josephowi Conradowi). Zatrzymaliśmy się także przy kościele św. Barbary, z którym jest związana niezwykle romantyczna historia miłości Eweliny Hańskiej i Honoriusza Balzaka. Po wieloletniej fascynacji i epistolarnej przyjaźni to właśnie w tej świątyni wzięli ślub. Odjeżdżając z miasta widzieliśmy z okien autobusu pałac Radziwiłłów oraz żydowski kirkut. Poszukując śladów polskości i łacińskiej, zachodniej kultury, nie mogliśmy nie zatrzymać się w jednym z jej centrów, w Żytomierzu. Zwiedziliśmy zachowaną w świetnym stanie katedrę rzymskokatolicką św. Zofii, widzieliśmy też pałac biskupi oraz prawosławny sobór Przemienienia Pańskiego. Niezapomniana była wizyta na polskim cmentarzu, gdzie, zaskoczeni mnogością polskich inskrypcji, przeszliśmy główną alejką. Jak się okazało, język ów nie jest już tylko domeną kamieni nagrobnych, bowiem spotkana przez nas starsza pani doskonale mówiła po polsku. Po Żytomierzu obraliśmy kierunek wschodni, a w drodze do ukraińskiej stolicy zatrzymaliśmy się w Korostyszowie. Odwiedziliśmy salezjańską placówkę oraz wysłuchaliśmy minikoncertu młodzieży w sali parafialnej. Wieczorem osiągnęliśmy najbardziej wysunięty na wschód punkt naszej wyprawy, Kijów. Zamieszkaliśmy w gościnnym klasztorze ojców dominikanów. Wolny czas można było wykorzystać dowolnie. Dzięki dobrej lokalizacji i połączeniom komunikacji miejskiej można było w krótkim czasie znaleźć się na głównym placu miasta, Majdanie Niezależności, oraz przejść się główną aleją Kijowa, Chreszczatykiem.

Niedziela minęła nam na zwiedzaniu naddnieprzańskiej metropolii. Jedną z podziemnych nitek metra dostaliśmy się w okolicę Ławry Peczerskiej. Zwiedzaliśmy niektóre z obiektów kompleksu: cerkwie Troicką i Trapezną, sobór Uspieński, wystawę przybliżającą historię miejsca oraz pieczary, miejsce pochówku otaczanych czcią mnichów. Powróciwszy do centrum miasta, zobaczyliśmy sobór Sofijski, mieszczący w swym wnętrzu m.in. bizantyjskie mozaiki z XI w. W ramach wolnego czasu można było według własnego uznania zwiedzić 
np. odbudowany niedawno sobór św. Michała Archanioła, rzymsko-katolicką katedrę św. Aleksandra, barokową cerkiew św. Andrzeja, przejść się brukowaną, opadającą stromo w dół uliczką Andrijiwśkyj Uzwiz czy wreszcie pojeździć kijowskim metrem. Możliwości było co niemiara.

Ostatni dzień podróży minął w podróży na trasie Kijów - Kraków. Z Żytomierza pojechaliśmy w kierunku Wołynia, zatrzymując się po drodze przy zamku Lubomirskich w Dubnie. Na wzgórzach w okolicy Lwowa widać było doskonale pałac Koniecpolskich w Podhorcach oraz zamek Sobieskich w Olesku. Dalsza droga wiodła przez Lwów, Korczową i Rzeszów. Pełni wrażeń dojechaliśmy o północy do Krakowa, mając nadzieję, że kolejny taki objazd odbędzie się już wkrótce. 